\title{
WATER QUALITY OF THE MONO RIVER AND HEALTH OF THE POPULATION IN THE COMMUNE OF ATHIEME IN SOUTH-WEST BENIN
}

\author{
Anselme K. SEDE ${ }^{1}$, Constant HOUNDENOU ${ }^{2}$ and Ernest AMOUSSOU ${ }^{2}$ \\ ${ }^{1}$ Department of Geography and Spatial Planning, University of Abomey-Calavi, 01 BP 526 Cotonou (Benin) \\ ${ }^{2}$ Pierre PAGNEY Laboratory: Climate, Water, Ecosystems and Development (LACEEDE), University of Abomey- \\ Calavi 03 BP 1122 Cotonou (Benin)
}

https://doi.org/10.35410/IJAEB.2020.5460

\begin{abstract}
The town of Athieme is a rural town with the characteristic of wetlands. The presence of the Mono river, ponds, backwaters, constitutes an important potential of water resources which can contribute to the socio-economic development of the commune. Mono river water is consumed by people and poses public health problems. The objective of this study is to contribute to the improvement of public health measures in the commune of Athiémé in the face of water problems.

The analysis is based on climatological data (1985-2015), physico-chemical and bacteriological data (2017), demographic statistics for RGPH4 (2013). The methodological approach used consisted of documentary research, field surveys, data processing and analysis of the results. The tools used are observation grids, questionnaires and interview guides. The Factor Analysis of Correspondences (FAC) allowed the analysis of the perception of socio-linguistic groups on activities, sources of water pollution. Physico-chemical and bacteriological tests revealed the poor quality of the river water.

The results showed that the water in the Mono River is contaminated and remains unfit for consumption. The practices of defecation, washing, washing dishes pollute the water. Indeed, palliative strategies for health problems are possible: the effective application of hygiene and sanitation texts, the treatment of water before drinking.
\end{abstract}

Keywords: Athieme, water, public health, pollution, local development

\section{INTRODUCTION}

Water plays a very important role in the life of societies and remains an undeniable vector of development provided that it is well managed. The health of men and their various activities fundamentally depend on it. Controlling water serves to support a country's socio-economic development by improving the health of its inhabitants (phillis \& al., 2006).

The physical environment and the climate are particularly favorable for the proliferation of certain diseases. The presence of water in the open air and often stagnant in hot climate, thrives various diseases. Where water goes, disease follows it (Bonou, 2004). 
In the Municipality of Athieme $43 \%$ of rural households do not have drinking water (EDS, 2006). Field investigations have shown that this situation has not improved more than eight (08) years later.

Wetlands are nests of disease. Indeed, the occupation of wetlands impacts the health of populations through diarrheal, respiratory and skin diseases due to the endemic conditions of wetlands for the maturation, development and proliferation of pathogens (Skinner \& al., 1994) .

The municipality of Athieme is no exception to these health problems linked to water. Health statistics (2017) on water and aquatic diseases and the results of physico-chemical and bacteriological tests have shown the presence of water-related diseases. This situation affects the development of socio-economic activities in the municipality. Observation on the ground showed the exercise of economic activities (agriculture, blacksmithing, gasoline and diesel fuel) and social practices (washing, dishes, defecation) damaging to the quality of the river water.

To conduct this study, three (03) questions emerge, namely: is the water from the Mono river a source of supply for the populations in the commune of Athieme? What are the main risk factors for diseases linked to river water in the Municipality? What are the main types of water-related diseases observed in the municipality?

The municipality of Athieme is located between $6^{\circ} 25$ 'and $6^{\circ} 40^{\prime}$ north latitude then between 1 ' 34 'and $1^{\circ} 38^{\prime}$ ' east longitude. It is bounded in the North by the Municipality of Lokossa, in the South by the Municipality of Grand-Popo, in the East by the Municipality of Houeyogbe and in the West by the Republic of Togo. 


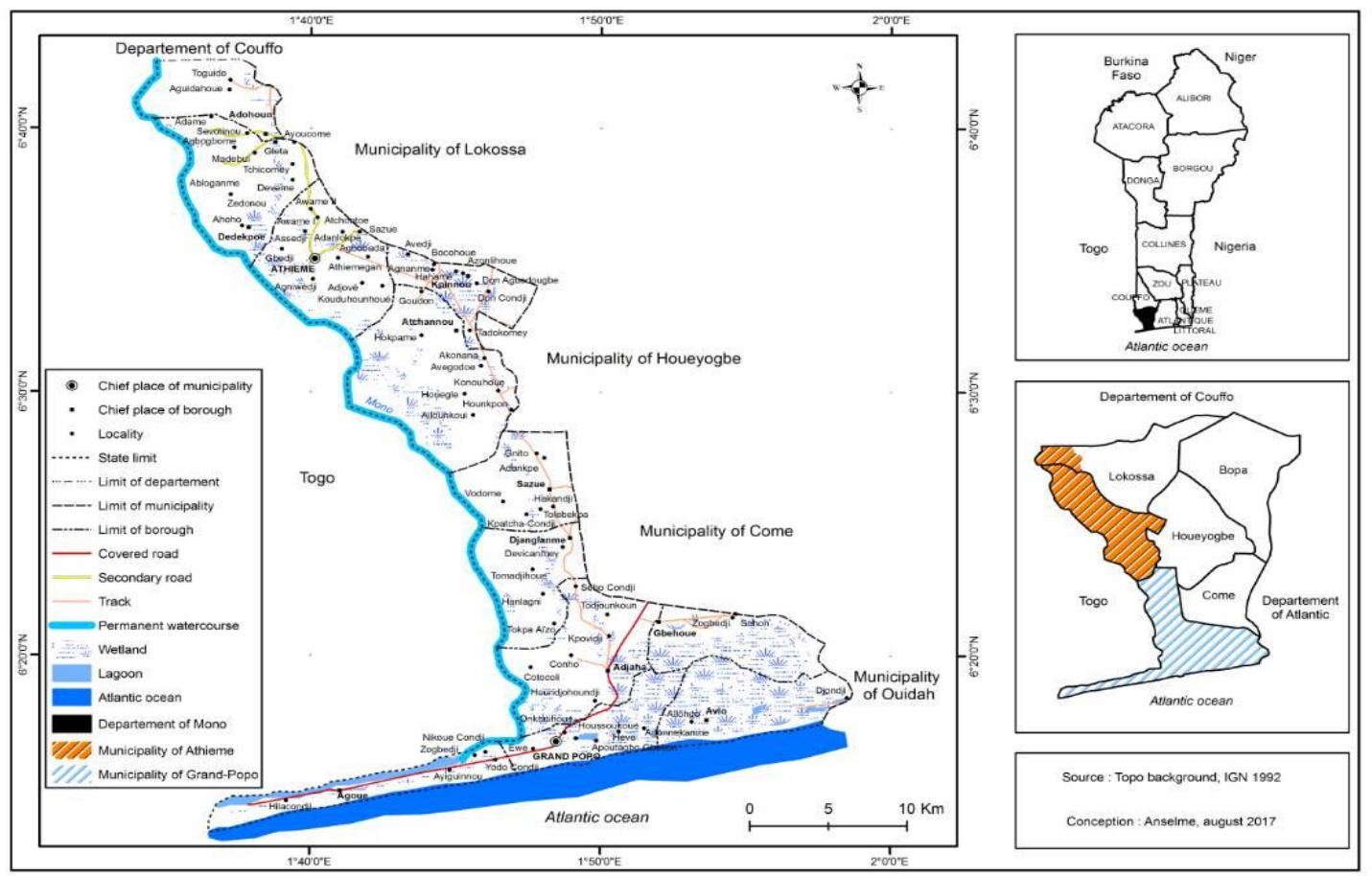

Figure 1: Geographic and administrative locations of the study area

\section{METHODOLOGICAL APPROACHES}

The data used in this work are climatological statistics obtained from ASECNA over the period from 1985 to 2015, health statistics, from the Ministry of Health (2007-2017), demographic statistics (RGPH3) collected at the Institute of Statistics and Economic Analysis (INSAE). The physico-chemical and bacteriological data were obtained following analyzes at the laboratory of the Directorate General for Water (DG / Water). Information on the pollution of the river water is collected in the field. The Life Routes Method made it possible to investigate the strategies defined by rural populations to curb the lack of drinking water resources and health problems linked to water.

Questionnaires, interview guides and observation grids were subject to manual examination. The data collected was captured and analyzed using Excel and SPSS software. The Factor Analysis of Correspondences (FAC) made it possible to appreciate the perception of the socio-cultural groups of the environment on the socio-economic activities which pollute the water of the river. Ten (10) social activities and practices are selected (washing, washing dishes, defecation, fun activities, sacrifice of sacrifices, exploitation of wood, trafficking in products, blacksmithing, fishing and agriculture) according to their importance collected in the study area and four (04) socio-cultural groups (Kotafon, Watchi, Adja and Fon). To better understand the factor analysis, you should read: Tour $=$ Tourism, Trac $=$ Gasoline and diesel traffic, Pech $=$ Fishing, Scrf $=$ Sacrifices of practices " vodoun ", Less $=$ Lessive, Defe $=$ Defecation, Forf $=$ Forge, Ludq $=$ Fun activities, Expl $=$ Exploitation of wood. The results of Pearson's correlation tests have shown the 
link between specific conditions (malaria, diarrheal diseases, gastroenteritis) and elements of the climate (rain, temperature).

For sampling, the choice of villages is made according to their proximity to the river. Preference is given to those who are located along the river or in its immediate perimeter and who are in permanent contact with water through different uses and socio-economic activities. Three villages were taken into account, namely: Ahoho, Aïwédji, Djonougoui, located respectively in the districts of Dedekpoe and Athieme.

The sample size is determined using Schwartz's (1995) formula with: $\mathrm{X}=\mathrm{Z} \alpha 2 \times \mathrm{PQ}$ / i2

$\mathrm{X}=$ sample size

$\mathrm{Z} \alpha=1.96$ reduced deviation corresponding to an $\alpha$ risk of $5 \%, \mathrm{P}=\mathrm{n} / \mathrm{N} ; \mathrm{P}=$ proportion of households selected

$\mathrm{Q}=1-\mathrm{P}$

(n) compared to the number of households in the 5 arrondissements $(\mathrm{N})$ in the municipality of Athiémé.

Table I shows the distribution of households to be surveyed.

Table I: Distribution of people to be surveyed in the Municipality

\begin{tabular}{|l|l|l|l|}
\hline Arrondissement & $\begin{array}{l}\text { Households } \\
\text { agricultural }\end{array}$ & $\begin{array}{l}\text { Number of households } \\
\text { surveyed }\end{array}$ & Proportion in \% \\
\hline Adohoun & 2125 & 73 & 27,95 \\
Atchannou & 1511 & 51 & 19,68 \\
Dédékpoé & 684 & 23 & 9,07 \\
Kpinnou & 1366 & 45 & 18,5 \\
Athiémè & 1841 & 60 & 24,8 \\
\hline Totals & $\mathbf{7 5 2 7}$ & $\mathbf{2 5 2}$ & $\mathbf{1 0 0}$ \\
\hline
\end{tabular}

Source: INSAE, 2004

A total of 252 households were surveyed in the commune.

\section{RESULTS}

3.1 Health Statistics and Disease Prevalence in 2017: Malaria, Diarrheal Diseases (DD), Gastroenteritis 
Analysis of Table I shows a strong positive correlation between Malaria / Rain $(r=0.57)$ and $\mathrm{DD} /$ Temperature $(\mathrm{r}=0.65)$ at the Threshold of significance $\alpha=0.05$.

Figures 1 and 2 show the seasonal pattern of malaria and rain followed by that of diarrheal disease and temperature. The increase in malaria cases is a function of the rain and the increase in cases of diarrheal diseases depends on the temperature. From April to July, period including the long rainy season, there is a high rainfall and an increase in malaria cases while from July to August, period of the small dry season, there is less rain and less malaria (Figure 1). From February to March (long dry season), there is a sharp increase in cases of Diarrheal Diseases (DD) at a temperature read at $30.5^{\circ} \mathrm{C}$ and a

Slight increase in disease cases from March to June, September-October and NovemberDecember. In July there is a decrease in cases with a temperature between $26^{\circ} \mathrm{C}$ and $29^{\circ} \mathrm{C}$ (Figure 2).

Table II: results of Pearson correlation tests.

\begin{tabular}{|l|r|l|l|l|}
\hline $\begin{array}{c}\text { Climate determinants } \\
\text { and correlated } \\
\text { conditions }\end{array}$ & $\begin{array}{c}\text { Correlation } \\
\text { coefficients } \\
(\mathbf{r})\end{array}$ & $\begin{array}{c}\text { Significance } \\
\text { rate (\%) }\end{array}$ & $\begin{array}{c}\text { Significance } \\
\text { threshold: } \boldsymbol{\alpha}\end{array}$ & Observations \\
\hline Malaria / Rain & 0,57 & $-0,17$ & $57 \%$ & $\mathrm{ST}$ \\
Diseases & $-0,02$ & $94 \%$ & $\mathbf{5 \%}$ & \\
Diarrheal / Rain & 0,33 & $30 \%$ & $\mathrm{ST}$ \\
Gastroenteritis / Rain & 0,65 & $02 \%$ & & \\
Malaria / Temperature & 0,33 & $29 \%$ & & \\
Diarrheal Diseases / & & & & \\
Temperature & &
\end{tabular}

Source: Pearson / SPSS correlation tests

Legend: ST: Significant Test 


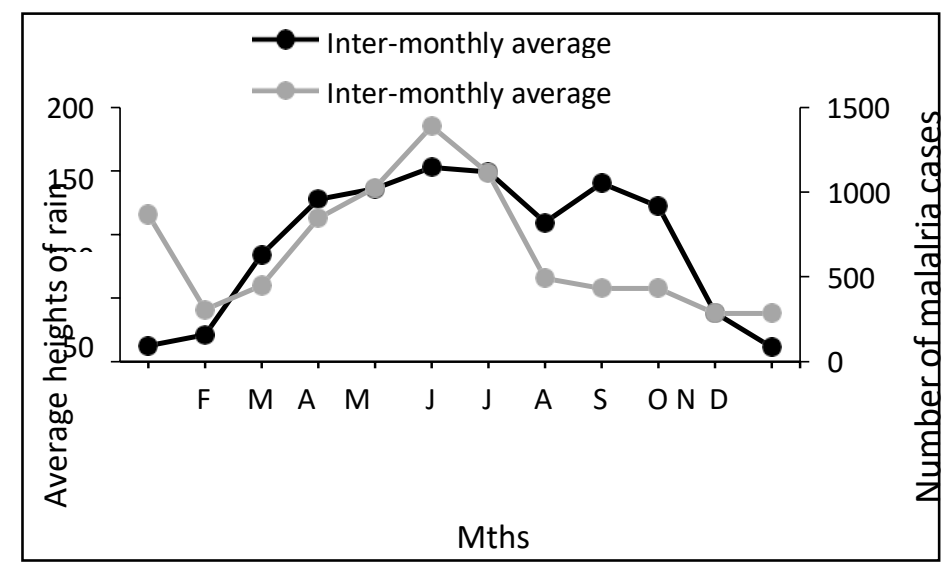

Figure 1: Evolution of malaria cases and variations in rainfall

Data source: ASECNA, 2015 and health statistics, 2017

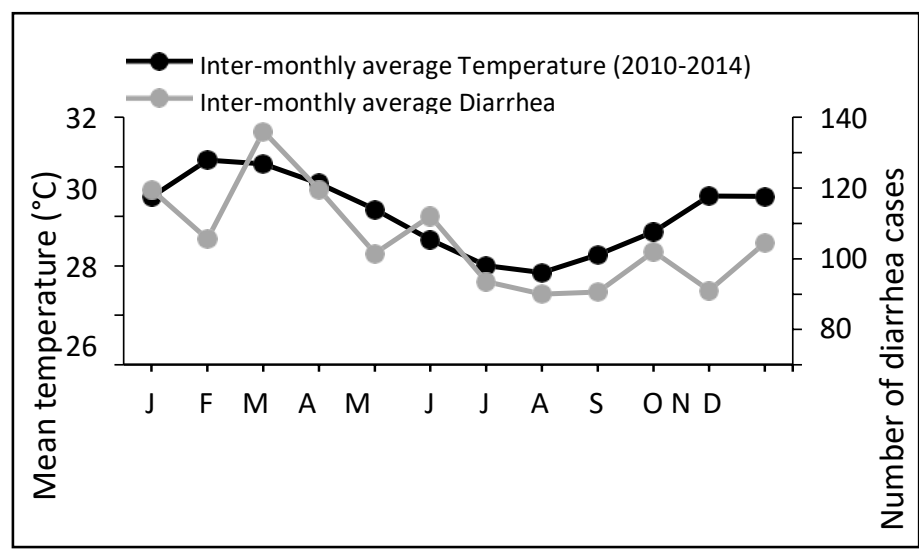

Figure 2: Variation of MD cases according to temperature

Data source: ASECNA, 2015 and health statistics, 2017

\section{2- Physico-chemical and bacteriological tests}

Table III provides an understanding of the standards (WHO) and the meaning of the physicochemical ( $\mathrm{PH}$, ammonium, COD, BOD) and bacteriological (fecal coliform, total coliform) parameters which contributed to the analysis of the quality of 1 river water. In the three (3) villages (Athiémé, Ahoho, Djonougoui) sampled, the PH remained below the norm and is higher in the dry season than in the rainy season (Figure 3). This increase can be explained by an increase in the concentration of ions in this season. The examination of Figure 4 has shown that in the dry season as in the rainy season, all the sampled waters have an ammonium content greater than $0.5 \mathrm{mg} / 1.67 \%$ of the samples taken during the rainy season have the highest levels. $33.33 \%$ of the waters experienced a strong increase in the dry season. The COD and BOD5 contents (Figures 5 and 6) of the water samples are included in the standards and reveal slight organic pollution of the river water. In the rainy season, the contents for the 2 parameters are the highest. Organic pollution is noted by the presence of piles of garbage near the Mono river. 
Bacteriological tests show that the highest total and fecal coliform levels are obtained in the dry season when the temperature is often high. In both the dry and rainy seasons, the concentration of coliform water is above the norm ( 0 coliform) due to the deposition of faeces and waste (Figures 7 and 8) in the water.

Plate 1 (photos a and b) actually shows the existence of a source of organic pollution by the ripple effect, the waste will end up in the river. The decomposition of organic matter from waste requires an amount of oxygen and can deplete the aquatic environment. Pollution therefore causes deoxygenation of the waters, which can lead to massive fish mortality (Gier, John, 2000 cited by Amoussou, 2009 and Babadjidé 2011)

Table III: Referent of physico-chemical and bacteriological tests

\begin{tabular}{|c|c|c|}
\hline Settings & WHO Standars & OBSERVATIONS \\
\hline Hydrogen potential $(\mathrm{PH})$ & $6,5-8,5$ & $\begin{array}{l}\text { parameter which allows to know } \\
\text { the concentration of }\end{array}$ \\
\hline Ammonium & $0,5 \mathrm{mg} / \mathrm{l}$. & ion water (WHO, 1994) \\
\hline $\begin{array}{l}\text { Chemical Oxygen Demand } \\
\text { Oxygène (COD) }\end{array}$ & $1-20 \mathrm{mg} / \mathrm{l}$ & $\begin{array}{l}\text { important determinant of } \\
\text { pollution of water by original } \\
\text { organic discharges }\end{array}$ \\
\hline $\begin{array}{l}\text { Biochemical Oxygen } \\
\text { Demand }\left(\mathrm{BOD}_{5}\right)\end{array}$ & $1-3 \mathrm{mg} / \mathrm{l}$ & $\begin{array}{l}\text { agricultural, domestic or } \\
\text { industrial (Lenntech, 2006) }\end{array}$ \\
\hline Coliforms (fecal, total) & 0 & $\begin{array}{l}\text { Amount of oxygen consumed by } \\
\text { the materials existing in the water } \\
\text { and oxidizable by chemical means } \\
\text { under the conditions }\end{array}$ \\
\hline
\end{tabular}

Source: WHO 1994, Lenntech 2006, Bontoux 1993, Eckenfelder 1982 


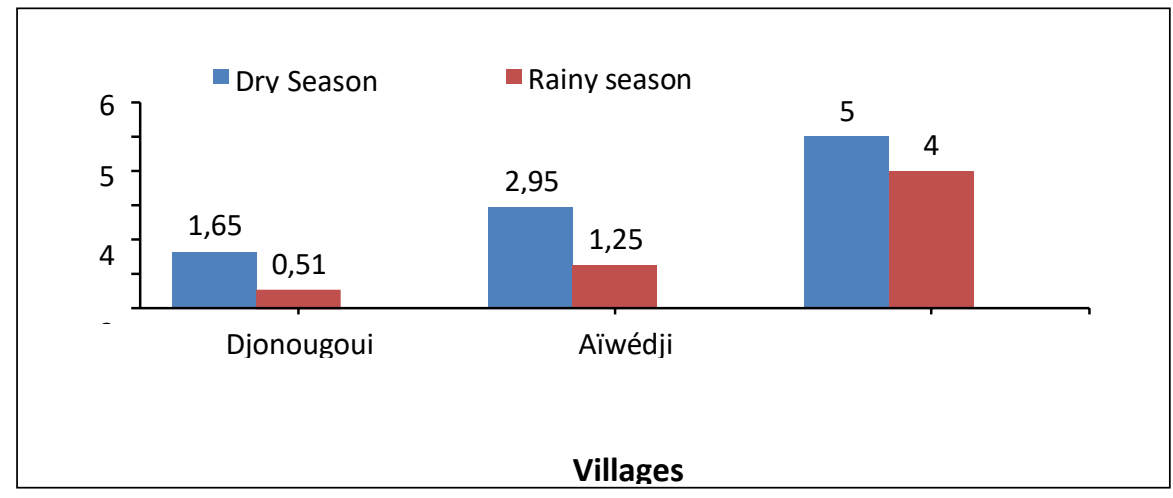

Figure 3: PH of the water samples taken, Source: Field surveys, 2017

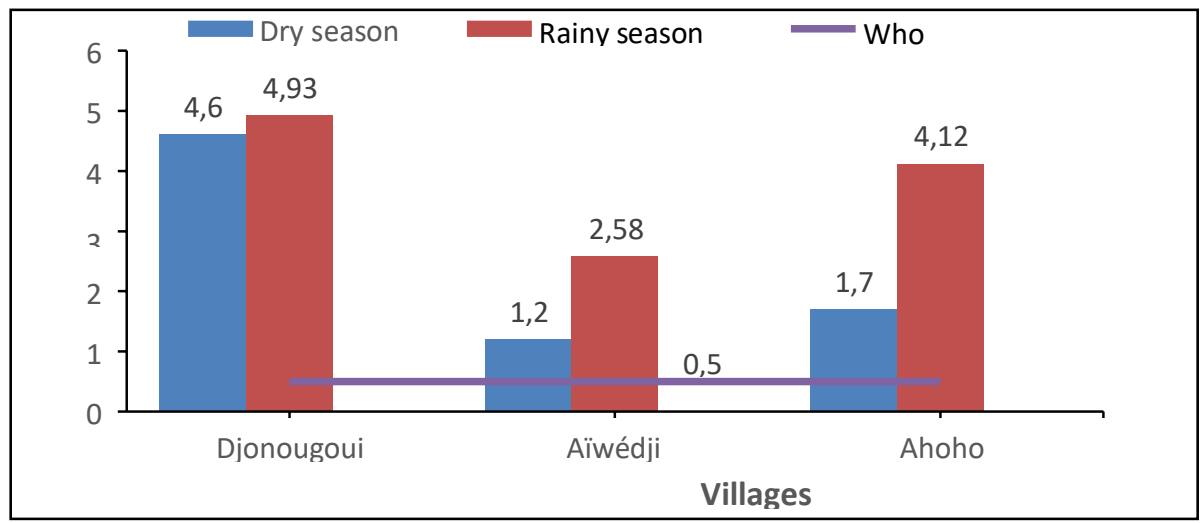

Figure 4: Ammonium content of water

Source: Field surveys, 2017

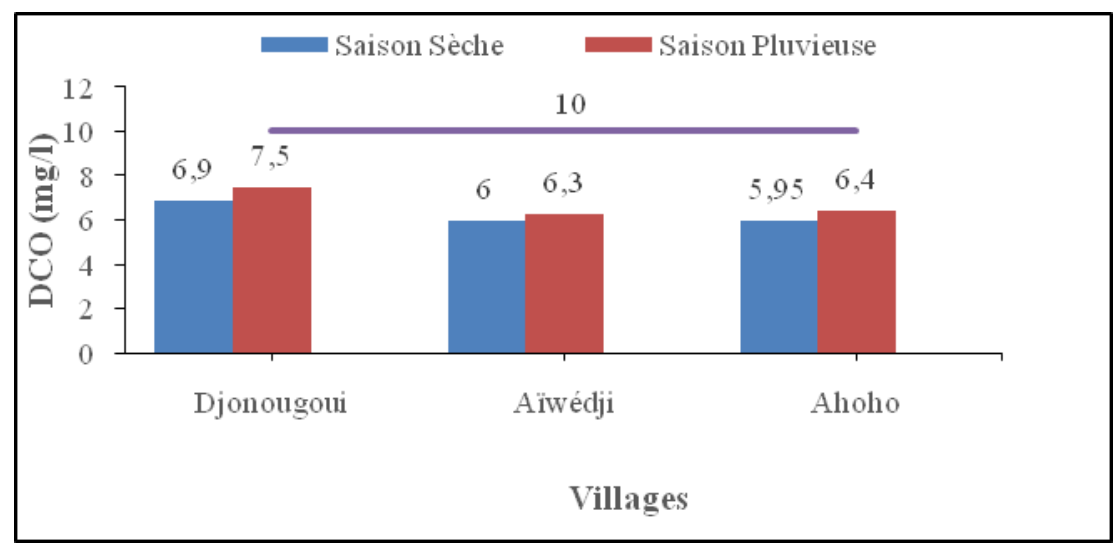

Figure 5: COD water content

Source: Field surveys, 2017 


\section{International Journal of Agriculture, Environment and Bioresearch}

Vol. 5, No. 01; 2020

ISSN: $2456-8643$
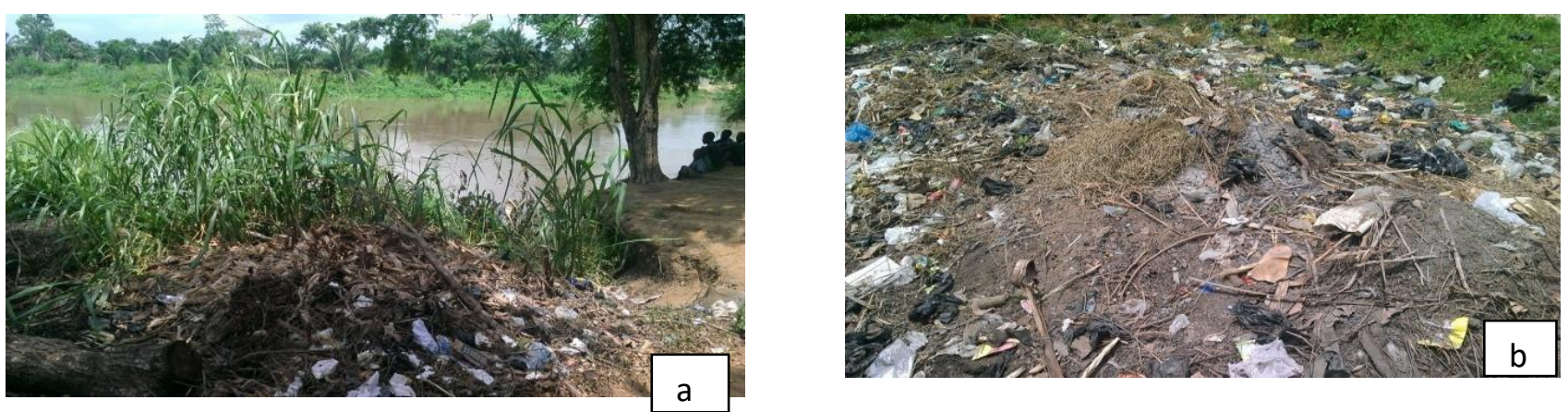

Plate 1: Pile of garbage at the river bank

Shooting: SEDE, 2017

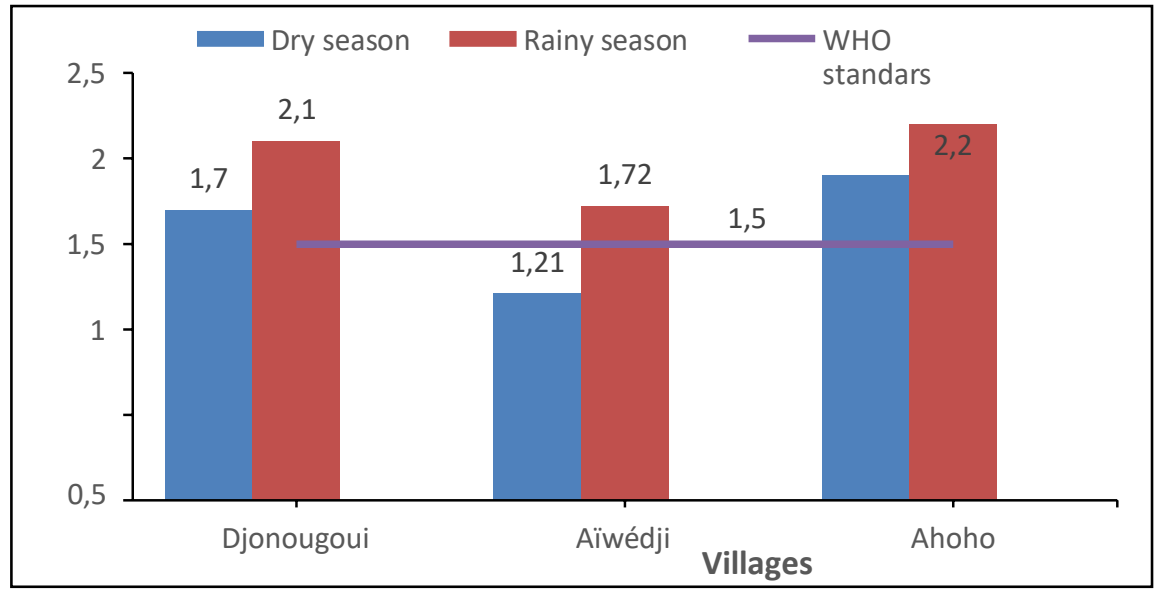

Figure 6: BOD5 water content, Source: Field surveys, 2017

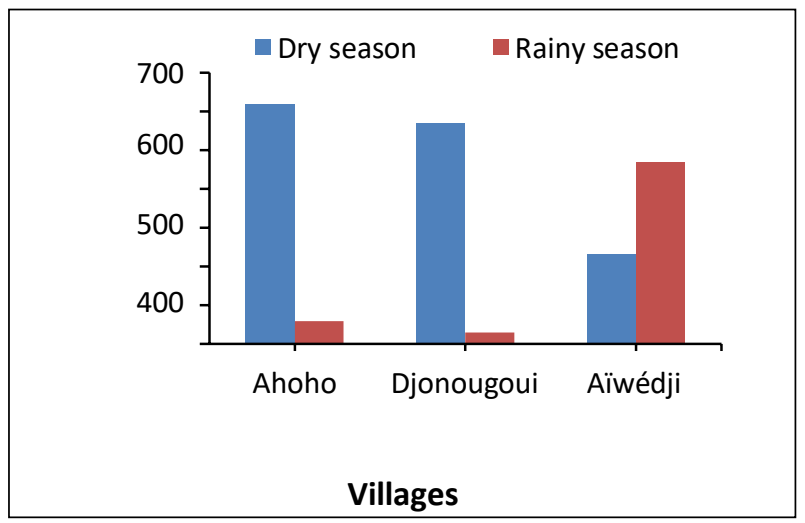

Figure 7: Coliform water content totals

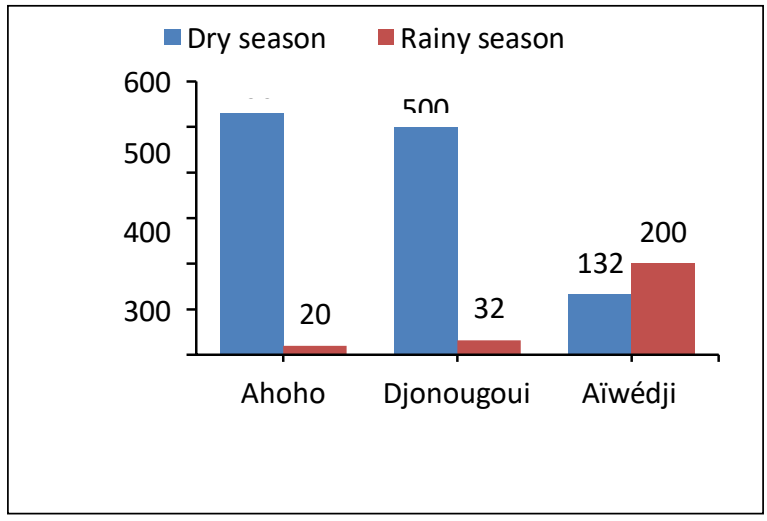

Figure 8: Coliform water content fecal

Source: Field surveys, 2017 


\section{3- Anthropogenic activities and impacts on river water}

Table III shows that the water component recorded more negative impacts induced by anthropogenic activities and sub-activities. In fact, the populations of the commune have divergent perceptions of the socio-economic activities that impact the river.

The first two planned axes explain $87.68 \%$ of the information on water pollution.

Axis 1 reveals that the Kotafons perceive fishing, transport and the sacrifices of "Vodou" as practices that pollute water unlike the Adjas who index Laundry, Defecation and Forge as polluting activities.

Axis 2: the fons recognize that Agriculture, Logging and Tourism are activities that degrade water quality.

\section{4- Foundations of the populations in favor of the consumption of water from the river}

$30 \%$ of respondents maintain that the use of river water for drinking, washing (plate 2), dishes (plate 2), bathing and others, is motivated by the limitation of purchasing power faced with the cost of water and the distance between the drinking water points of the villages. $70 \%$ of those surveyed reveal that the consumption of water from the Mono river is a parental heritage and postulate the argument that "their grandparents lived by consuming this water for a long time without dying of it" and that water from Mono river is not stagnant. Consequently, they forget by ignorance that the elimination of waste by water currents absolutely lacks logic, since at a point " $\mathrm{C}$ " where the water is being drunk, pollution (urine , defecation, washing or washing up...) caused at point " A " and or " B " absolutely and negatively influences point " C " where water is consumed. This practice puts human health at risk.

Table III: Adapted from Léopold (1979)

\begin{tabular}{|c|c|c|c|c|}
\hline \begin{tabular}{|c|} 
Middle components \\
Activities / sources of impact
\end{tabular} & Water & Wildlife & Flora & Health \\
\hline $\begin{array}{l}\text { Use of fertilizers and } \\
\text { pesticide }\end{array}$ & - & $\begin{array}{c}+- \\
-\end{array}$ & - & - \\
\hline Bush fires & - & - & - & - \\
\hline Prohibited fishing techniques & - & & & - \\
\hline Laundry & - & & & - \\
\hline Dishes & - & & & - \\
\hline
\end{tabular}


Legend: positive impact (+); negative impact (-) / Source: Adapted from Léopold, 1971

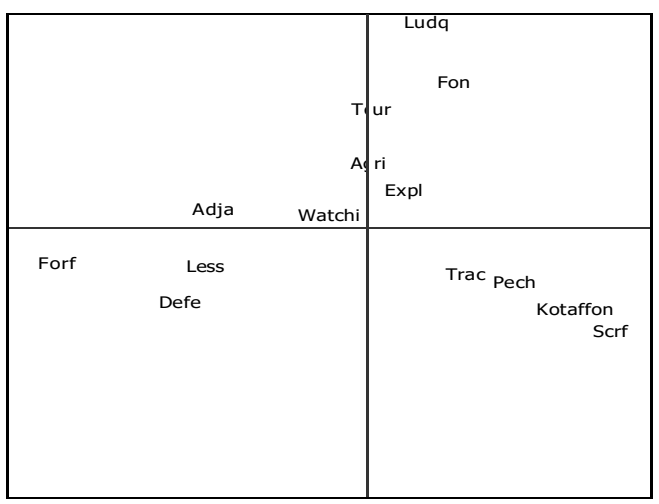

Figure 9: Socio-cultural groups and polluting activities (FAC)

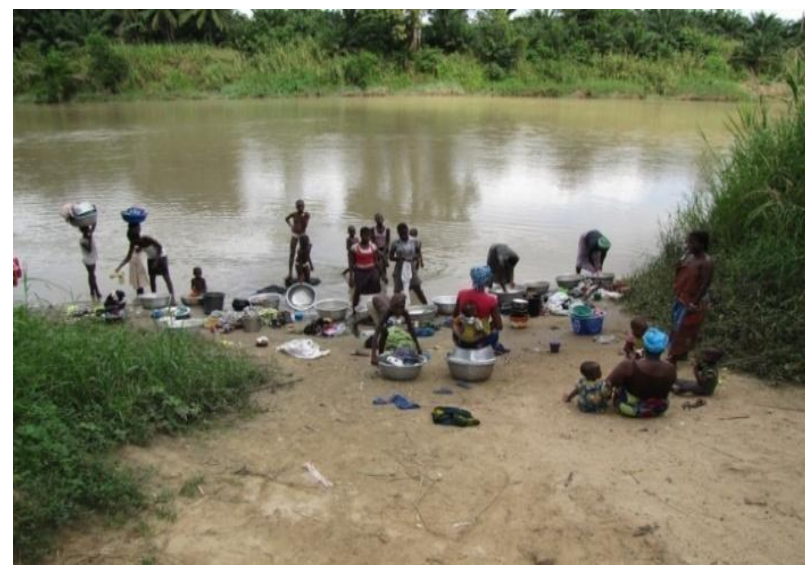

C

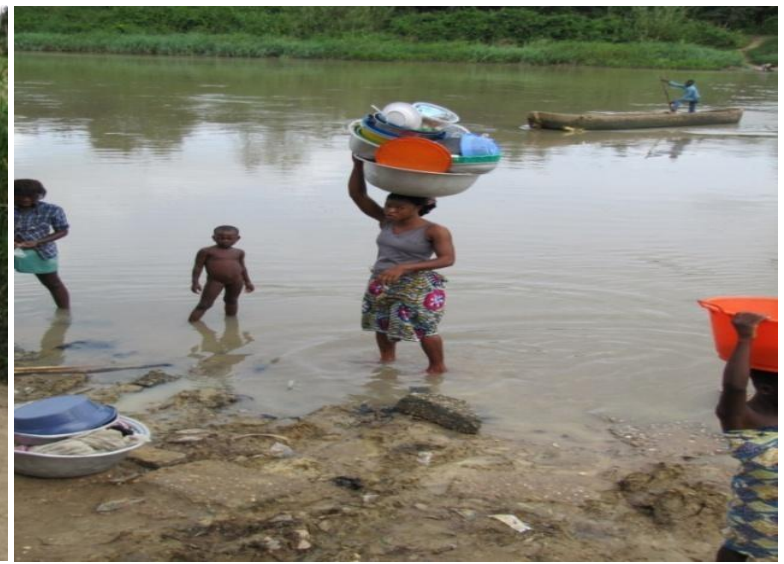

d

Plate 2: Laundry and Dishes in the Mono River at Athiémé

\subsection{DISCUSSION}

The results of our research have shown that the water in the Mono River is polluted and poses health problems for people. This pollution is accentuated by the negative impact of various anthropogenic activities on the river. The consumption of this surface water by populations leads to the manifestation of water-related diseases. These diseases are influenced by the elements of the climate. The results of Babadjidé's work (2011) point in the same direction and note the poor water quality in the Mono river basin. The results of the author's work have shown that practices (defecation, washing, washing dishes, fertilizer use in agriculture) have further degraded the quality of water in the Mono River. These results confirm our work and reveal that the consumption of surface water poses health risks for the health of populations. The results of the work of Ogou (2009) in the commune of Save, of Zannou (2009) in the commune of Sakete are 
also in agreement with our study on water and the public health problems posed by the consumption of water from surface exposed to polluting factors. The same is true of the work of Houssou et al., (2006) in the Mono department on the relationships between water-related diseases and climatic parameters.

\section{CONCLUSION}

Physico-chemical and bacteriological tests and the impact of economic and social practices on water have shown that the water in the Mono River is of poor quality.

The content of water in COD, BOD5 and the presence of fecal and total coliforms mainly express the level of organic pollution due to the deposition of faeces in the river bed and the effect of dragging waste into the river by rainwater. The degradation of organic matter from these deposits requires an amount of oxygen and remains a source of organic pollution. Some strategies are proposed to curb water pollution: effective treatment of river water before drinking, compliance with hygiene and sanitation rules (regular washing of water conservation containers), the erection of a Special River Police (SRP), the erection of public and domestic latrines, the effective application of hygiene and sanitation sanctions, the installation of clean water supplies in each village from the community.

\section{REFERENCES}

Amoussou C. C.C, 2009. Contamination of toxic metals from the Grand-Popo coastal lagoon: inventory and consequences for fishery products. DEA thesis at EDP, UAC / FLASH, 77 p.

Babadjidé, 2009. Influences of water pollution on human health in the Mono basin in Benin. EDP Doctoral Thesis, UAC, 288 p.

Bonou G. 2004. Socio-sanitary impact of the agricultural exploitation of wetlands in South Benin: case of the districts of Kpanroun and Zinvié commune of Abomey-Calavi; Master of Geography thesis; DGAT / FLASH / UAC, 95 p.

Eckenfelder, W., 1982. Management of urban and industrial wastewater: characterization, purification techniques and economic aspects. Paris: Lavoisier-Tec and doc., $24 \mathrm{p}$

Houssou C.S., Vissin E. W., Perard J., 2006. Climatic variability and pathology in the Mono department (Benin, West Africa) AIC conference, Epernay, 8 p.

Ogou J. 2009. Drinking water supply and health problems in rural areas: case of the district of kaboua commune of savè; Master of Geography thesis; DGAT / FLASH / UAC, 30 p.

John P. 2000: Water quality policy. Wateraid, Madagascar, 65 p.

WHO, 1994. Quality guidelines for drinking water. Geneva, 202 p.

Skinner J., Beaumond N., Pirot J. Y., 1994. Training manual for tropical wetland management, World Conservation Union, $272 \mathrm{p}$. 
Zannou S. (2009). endogenous management of water resources in the sakété commune; Master of Geography thesis; DGAT / FLASH / UAC, 45 p.

Web sites

WHO Collaborating Center, 2007. www.pseau.org ... Accessed April 10, 2016

Phillips, D.J.H., M. Daoudy, S.C. McCaffrey, J. Öjendal et A.R. Turton, 2006. Water control and sustainable development in West Africa: https://vertigo.revues.org. Accessed November 12, 2015 